Kampus 4 Universitas Ahmad Dahlan Jl. Ringroad Selatan, Tamanan, Banguntapan, Bantul

Daerah Istimewa Yogyakarta 55191

Telp. : (0274) 563515 Fax. : (0274) 564604

e-mail : ihtifaz@uad.ac.id

Vol.1, No 1\&2, Juni-Desember 2018, pp. 147-157 ISSN p:2622-4755 e:2622-4798.

DOI: https://doi.org/10.12928/ijiefb.v1i1.270

\title{
Analisis Votalitas Saham di Jakarta Islamic Index (JII) periode Januari 2015-Januari 2018
}

\section{Hendri Tanjung ${ }^{1}$, Taufik Akbar Martua Siregar $^{1}$}

${ }^{1}$ Universitas Ibn Khaldun, Jl. Baru, Kedung Badak, Tanah Sereal,

Kota Bogor, Jawa Barat, Indonesia

*e-mail: hendri.tanjung@gmail.com 


\section{Analisis Votalitas Saham di Jakarta Islamic Index (JII) periode Januari 2015-Januari 2018}

\author{
Hendri Tanjung ${ }^{1}{ }^{1}$, Taufik Akbar Martua Siregar ${ }^{1}$ \\ ${ }^{1}$ Universitas Ibn Khaldun, Jl. Baru, Kedung Badak, Tanah Sereal, \\ Kota Bogor, Jawa Barat, Indonesia \\ *e-mail: hendri.tanjung@gmail.com
}

\begin{abstract}
This study aims to look at the volatility of the Jakarta Islamic Index (JII) on the Jakarta Stock Exchange. The analysis technique used in this study is the Generalized Autoregressive Conditional Heteroscedasticity (GARCH) and Autoregressive Conditional Heteroscedasticity (ARCH). Normality of the level of return distribution at JII is analyzed to answer whether the return is spread normally or not. By using JII data from January 2015 to January 2018 (724 daily data), it was found that the distribution of return JII did not spread normally. This study concludes that the return from the Jakarta Islamic Index is very fluctuating. The implication is that there will be very high proffis and very large losses on one day.
\end{abstract}

\section{Keywords:}

Volatility, Normal Distribution, Jakarta Islamic Index

\begin{abstract}
Abstrak
Penelitian ini bertujuan untuk melihat volatilitas Jakarta Islamic Index (JII) pada Jakarta Stock Exchange. Adapun teknik analisis yang digunakan pada penelitian ini adalah Generalized Autoregressive Conditional Heteroscedasticity (GARCH) dan Autoregressive Conditional Heteroscedasticity (ARCH). Kenormalan distribusi tingkat return pada JII dianalisis untuk menjawab apakah return-nya tersebar secara normal atau tidak. Dengan menggunakan data JII dari januari 2015 sampai dengan januari 2018 (724 data harian), ditemukan bahwa distribusi dari return JII tidak menyebar normal. Penelitian ini menyimpulkan bahwa return dari Jakarta Islamic Indeks sangat berfluktuasi. Adapun implikasinya adalah akan diperoleh keuntungan yang sangat tinggi dan kerugian yang sangat besar pada satu hari.
\end{abstract}

\section{Kata Kunci:}

Volatilitas, Distribusi Normal, Jakarta Islamic Index

Ihtifaz: Journal of Islamic Economics, Finance, and Banking

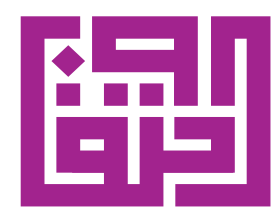

IHTIFAZ

UNIVERSITAS AHMAD DAHLAN

Kampus 4

Universitas Ahmad Dahlan Universitas Ahmad Dahlan
J. Ringroad Selatan, Tamanan Banguntapan, Bantul Yogyakarta 55191 


\section{PENDAHULUAN}

Perkembangan perekonomian suatu negara tidak lepas dari kondisi IHTIFAZ - JIEFB investasi didalamnya. Semakin maju suatu negara maka semakin besar peran investasi. Pada negara maju, peran pasar modal lebih besar daripada institusi perbankan didalam menyalurkan dana ke sektor produktif. Dewasa ini perkembangan pasar modal terus mengikuti perkembangan sistem keuangan yang ada. Salah satu pembaharuannya adalah pasar modal berbasis syariah yang mengikuti perkembangan industri keuangan syariah. Di Indonesia, Jakarta Islamic index (JII) merupakan pasar modal yang menggunakan mekanisme pasar modal syariah. Dengan penduduk yang mayoritas muslim, pemerintah Indonesia menggunakan JII dalam memainkan perannya untuk perekonomian nasional.

Sangat penting untuk menjaga iklim investasi nasional agar investor merasa aman dalam menginvestasikan dananya. Dalam berinvestasi saham, ada dua hal penting yang harus diperhatikan yaitu tingkat bagi hasil (return) dan resiko. Pada umumnya, investor ingin mendapatkan return yang maksimal dengan resiko yang minimal. Untuk mengetahui tingkat return dan risiko, yang seringkali dijadikan acuan adalah tingkat volatilitas return saham.

Volatilitas yang tinggi mengindikasikan harga dapat naik tinggi secara cepat namun dapat juga turun secara tiba-tiba. Kondisi ini menjadi perhatian bagi para investor karena resiko yang ada. Sangat beralasan bagi investor untuk hati-hati dalam membeli dan menjual sahamnya. Adapun cara sederhana dalam mengetahui tingkat volatilitas adalah dengan menghitung distribusi normal. Oleh karena itu, penulis ingin mengetahui:

1. Apakah return saham di JII terdistribusi secara normal?

2. Berapa besar tingkat volatilitas di JII?

Tujuan dari penelitian ini adalah untuk mengetahui apakah distribusi return di JII normal atau tidak, mengetahui tingkat volatilitas di JII, dan mengetahui karakteristik return saham dan model votalitas return saham.

\section{TINJAUAN TEORITIS DAN LITERATURE}

Pasar modal syariah merupakan kegiatan pasar modal yang tidak bertentangan dengan prinsip syariah islam. Di Indonesia, pasar modal syariah memiliki peran sebagai sarana investasi efek syariah bagi investor dan sebagai sumber pendanaan bagi perusahaan dalam mengembangkan usahanya, dengan cara menerbitkan efek syariah. Kegiatan pasar modal syariah melibatkan investor didalamnya. Dalam hal ini, tujuan investor berinvestasi tidak lain adalah untuk mendapatkan capital gain dan deviden. Dalam pelaksanaannya, investor juga 
berhadapan dengan resiko kerugian atau Capital loss. Adapun beberapa tipe investor dilihat dari sudut pandang kesediaannya mendapatkan resiko adalah: pertama, Investor yang berani mengambil resiko (risk taker/lover risk/risk seeker); kedua, investor yang takut atau enggan mengambil resiko (risk averter/risk aversion); dan Ketiga, Investor yang tidak takut tetapi juga tidak berani atau biasa disebut risk moderate/ moderate investor.

Dalam melakukan investasi, para investor harus mengetahui

beberapa faktor yang mempengaruhi volatilitas harga saham guna menentukan keputusan yang akan diambil. Di Indonesia, ada beberapa faktor yang mempengaruhi volatilitas harga saham, diantaranya adalah: pertama, kabar buruk/isu buruk dari luar negeri yang dalam hal ini adalah pergerakan mata uang dollar Amerika; kedua, kebijakan dalam negeri misalnya pelonggaran pasokan uang rupiah. Kondisi tersebut membutuhkan management resiko yang baik guna mendapatkan keuntungan dan mengurangi kerugian bila terjadi penurunan nilai.

Adapun macam-macam resiko dibagi menjadi dua yaitu: resiko pasif dan resiko responsive. Resiko pasif seperti halnya game of chance, hanya mengandalkan keberuntungan. Resiko responsive adalah yang memungkinkan adanya probabilitas hasil keluaran dengan hubungan kausitas yang logis (game of skill). Kesediaan menanggung resiko merupakan hal yang tidak bisa dihindarkan dalam berinvestasi di pasar modal. Untuk meminimalisir resiko tersebut, dibutuhkan pengetahuan sebagai game of skill bukan game of chance.

Jakarta Islamic Index atau biasa disebut JII adalah salah satu indeks saham yang beroperasi di Indonesia. Dalam kegiatannya, JII menghitung indeks harga rata-rata saham untuk jenis saham-saham yang memenuhi kriteria syariah. Pada penelitian sebelumnya, ditemukan bahwa ada tiga faktor yang paling mempengaruhi volatilitas harga saham syariah di Indonesia diantaranya adalah harga CPO, nilai Inflasi dan kebijakan dalam negeri. Adapun kondisi makroekonomi internasional seperti kebijakan the FED atau Dow Jones tidak terlalu berpengaruh dalam tingkat volatilitas harga saham syariah di Indonesia.

Al-Najjar (2016) menemukan bahwa terdapat volatilitas pada return saham yang listing di Amman Stock exchange (ASE) Jordan periode 1 Januari 2005 sampai 31 desember 2014. Lebih jauh, dengan menggunakan EGARCH model, menghasilkan bahwa tidak ada dukungan keberadaan leverage effect pada return di ASE. Nastiti dan Suharsono (2012) meneliti saham perusahaan besar seperti PT Aneka Tambang (persero) dan PT. Semen Gresik (persero). Dari analisisnya terhadap volatilitas kedua perusahaan tersebut, disimpulkan bahwa saham semen gresik memiliki potensi risiko lebih tinggi daripada saham aneka tambang.

Tanjung (2014) menemukan bahwa return saham JII untuk periode 2 Maret 2009 sampai 30 oktober 2013 (1122 data harian) terdistribusi tidak normal. Ini akan membuat keuntungan yang besar di satu hari, dan kerugian yang besar juga tercipta di satu hari. 


\section{DATA DAN METODE}

Data pada penelitian ini diperoleh dari Jakarta Islamic Index (JII) IHTIFAZ - JIEFB terhitung dari periode januari 2015 sampai dengan januari 2018. Jumlah data yang dianalisis pada penelitian ini adalah 724 data harian return di JII. Penelitian ini menggunakan metode kuantitatif. Metode kuantitatif adalah suatu metode penelitian yang mementingkan percobaan, kuantifikasi (perhitungan matematis), verifikasi empiris, objektivitas, dan lebih bersifat netral. Metode kuantitatif bertujuan untuk menjelaskan hubungan atau pengaruh yang terukur, untuk meramalkan dan mengontrol berdasarkan data yang didapatkan dari laporan-laporan yang sudah dipublikasikan dan sudah tersedia, sehingga memberikan informasi untuk menganalisa masalah yang diselidiki. Data yang digunakan dalam penelitian ini adalah data sekunder dan diolah dengan menggunakan metode ARCH - GARCH.

Analisis GARCH terdiri dari beberapa langkah sebagai berikut:

1. Langkah pertama adalah melakukan analisis data dengan menggunakan metode ARMA untuk mengetahui apakah ada korelasi serial di dalam data atau tidak. Model ARMA seharusnya tidak boleh terjadi korelasi residual di dalam data yang berarti nilainya harus mendekati nol.

2. Langkah kedua menguji apakah terjadi heteroskedasitas atau tidak. Ada beberapa tes yang bisa digunakan seperti Box- Pierce tests, Ljung-Box tests, dan lain-lain. Suatu metode statistik yang sesuai yang bisa digunakan jika terjadi heteroskedasitas adalah dengan menggunakan GARCH.

3. Langkah ketiga adalah dengan melakukan uji koefisien autokerelasi parsialnya, hal ini ditujukan untuk mengetahui model GARCH yang lebih spesifik. Ini merupakan suatu proses yang normal, kemudian dilakukan pendugaan parameter dengan menggunakan teori kemungkinan maksimum (maximum likelihood).

4. Langkah terakhir adalah memeriksa apakah model GARCH yang digunakan telah sesuai atau tidak.

Konsep bahwa perubahan harga-harga merupakan proses white noise terlalu sempit untuk data finansial dan yang diperlukan adalah suatu martingale. Martingale adalah proses stokastik yaitu model matematik dari suatu fair game secara formal. Martingale didefinisikan sebagai suatu urutan peubah acak (proses stokastik $X_{t}(t=1,2, \ldots)$ yang pada waktu tertentu, ekspektasi bersyarat dari nilai berikutnya dalam urutan, sama dengan nilai sekarang, mengingat semua nilai sebelumnya.

\section{PEMBAHASAN}

Mengawali pembahasan ini, menjadi penting untuk melihat data harian dari JII yang terdapat pada Bursa Efek Jakarta (BEJ) dan mencari 
tahu apakah return dari JII tersebut normal atau tidak. Pertama, dapat dilihat jumlah data yang terdiri dari 724 terhitung dari januari 2015 sampai dengan januari 2018.

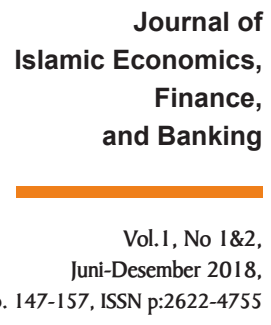

ktuasi sepanjang periode pengamatan. pp. 147-157, ISSN p:2622-4755 e:2622-4798

Gambar 1. Histogram return JII periode 30 Januari 2015-30 januari 2018

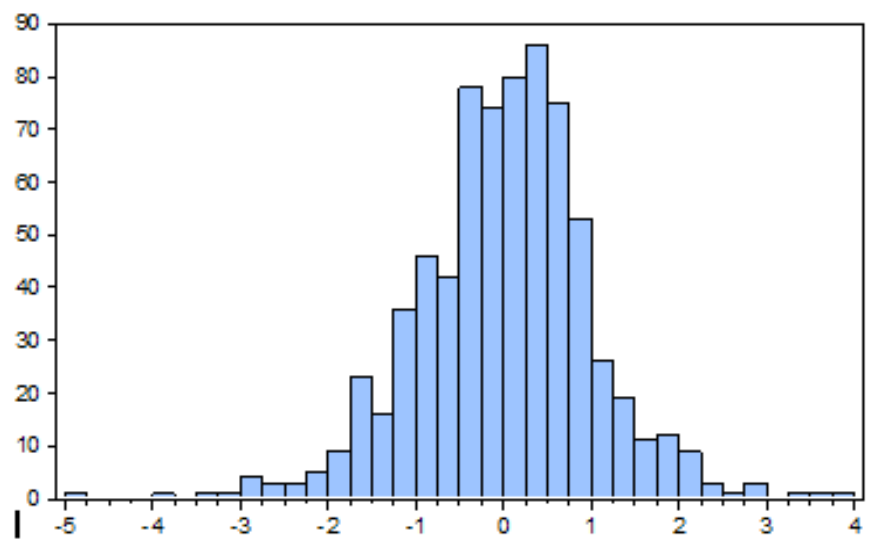

Dari histogram 1 di atas dapat diduga bahwa sebaran return JII tidak normal. Rata-rata hasil pengamatan pada JII adalah 0,011122 yang menunjukkan bahwa ada keuntungan selama priode pengamatan. Standard deviasinya 1,000718 . Ada juga perbandingan nilai maximum $-4,92586$ yang menunjukkan variabilitas perubahan harga dan kurtosis 4.72296 serta skewness $-0,212788$. Data ini menunjukkan bahwa distribusi miring dan tidak terdistribusi secara normal. Hasil uji Jarque - Bera 95,15510 juga konsisten dengan nilai kurtosis dan kemiringan sebelumnya yang memiliki tingkat signifikasi pada level $1 \%, 5 \%$ dan $10 \%$ yang berarti menolak Hipotesis Nol dan menerima hipotesis alternatif yang menyatakan hasil pengamatan tidak terdistribusi secara normal.

Gambar 2. Time series return JII periode 30 Januari 2015-30 Januari 2018

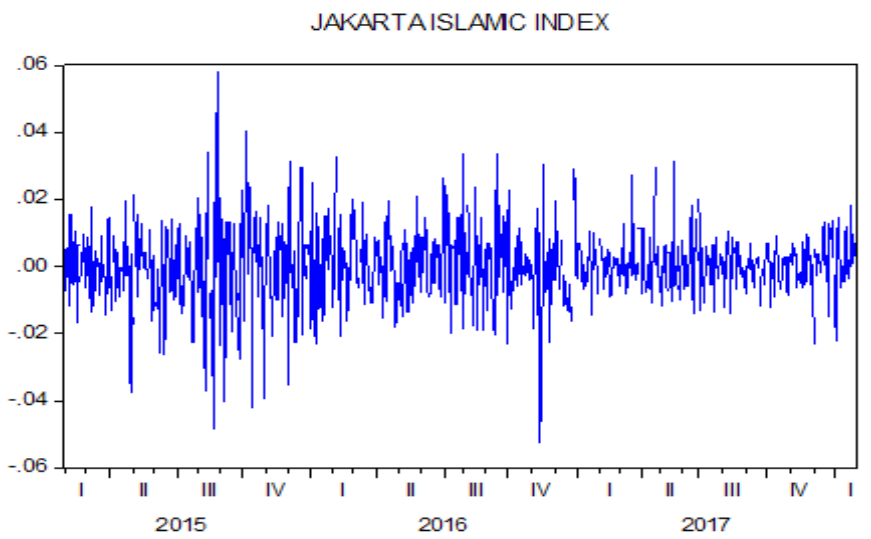

Ihtifaz: Journal of Islamic Economics, Finance, and Banking 
Selanjutnya, menggunakan grafik visual dari JII kembali selama periode pengamatan, dapat diketahui bahwa perubahan votalitas dari IHTIFAZ - JIEFB waktu ke waktu cenderung mengelompokkan returnnya.

Tabel 1. ADF Test untuk variable 'Return' dari JII

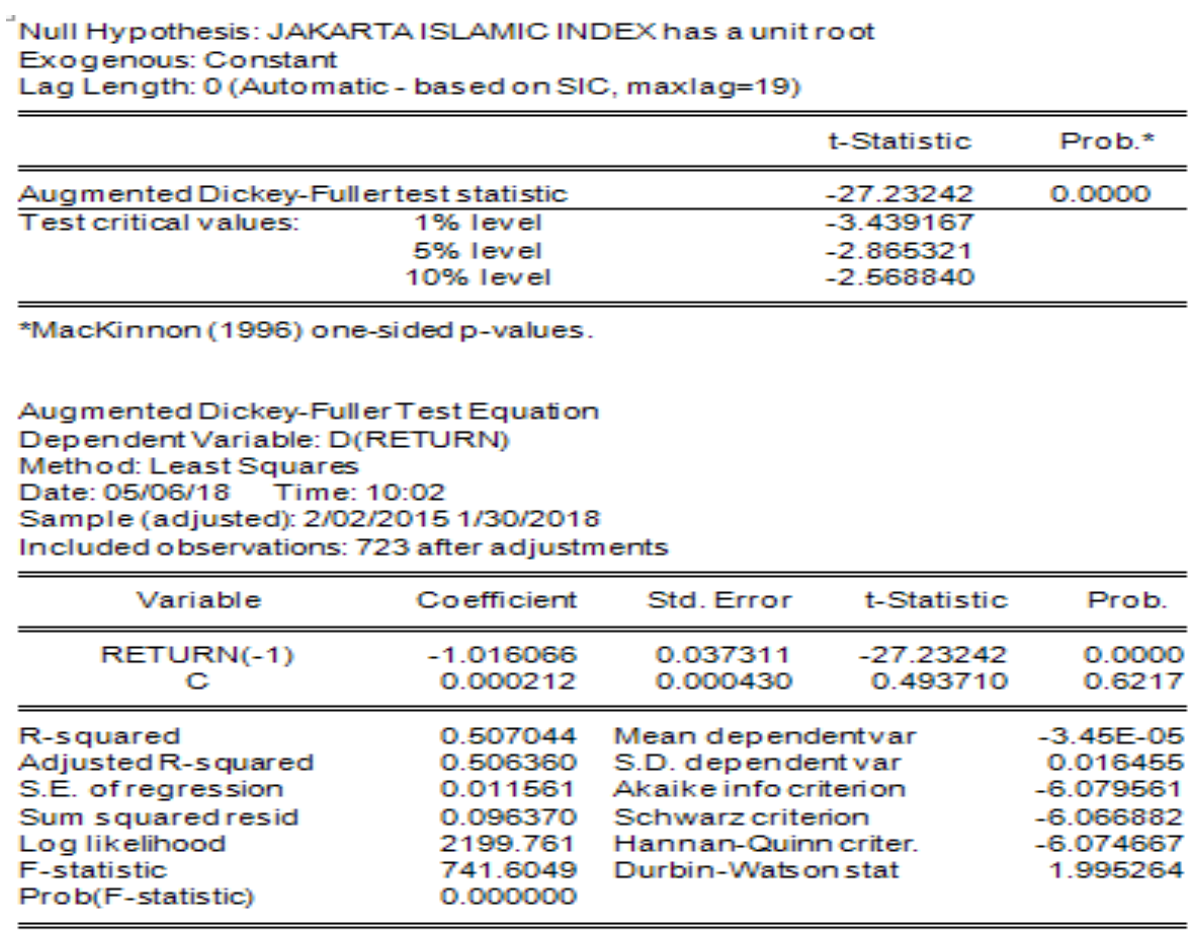

Sumber: Output Eviews Versi 9.

Tabel 1 menunjukkan bahwa hasil uji Augmented Dickey-Fuller(ADF) untuk memeriksa akar unit dalam series return nya. Hasil ADF secara statistik signifikan pada tingkat $1 \%$ yang menolak hipotesis nol yang menunjukkan bahwa return nya adalah stasioner. Karena data bersifat tidak stasioner (berdasarkan uji ADF), maka dilakukan diferensiasi dan ditemukan bahwa datanya stasioner pada diferensiasi pertama. Langkah selanjutnya adalah menentukan persamaan rata-rata yang paling sesuai melalui penerapan Auto Regressive Moving Average (ARMA). Untuk memilih proses terbaik dalam pemodelan mean kondisional, dapat dinyatakan sebagai model berikut:

$$
r_{t}=\phi_{1} r_{t-1}+\varepsilon_{t}+\theta_{1} \varepsilon_{t-1}
$$

Setelah membangun model ARMA untuk memperkirakan rata-rata, volatilitas akan dimodelkan menggunakan kedua model ARCH / GARCH. 
Tabel 2. ARCH test

Heteros kedasticity Test: ARCH

\begin{tabular}{|c|c|c|c|c|}
\hline $\begin{array}{l}\text { F-statistic } \\
\text { Obs*R-squared }\end{array}$ & $\begin{array}{l}0.015900 \\
0.015944\end{array}$ & \multicolumn{2}{|c|}{$\begin{array}{l}\text { Prob. } F(1,721) \\
\text { Prob. Chi-Square(1) }\end{array}$} & $\begin{array}{l}0.8997 \\
0.8995\end{array}$ \\
\hline \multicolumn{5}{|c|}{$\begin{array}{l}\text { Test Equation: } \\
\text { Dependent Variable: WGT_RESID } 2 \\
\text { Method: Least Squares } \\
\text { Date: O5/O6/18 Time: } 10: 13 \\
\text { Sample (adjusted): } 2 / 02 / 20151 / 30 / 2018 \\
\text { Included observations: } 723 \text { after adjustments }\end{array}$} \\
\hline Variable & Coefficient & Std. Error & t-Statistic & Prob. \\
\hline WGT_RESID $2(-1)$ & $\begin{array}{r}1.005790 \\
-0.004700\end{array}$ & $\begin{array}{l}0.089922 \\
0.037272\end{array}$ & $\begin{array}{r}11.18516 \\
-0.126094\end{array}$ & $\begin{array}{l}0.0000 \\
0.8997\end{array}$ \\
\hline $\begin{array}{l}\text { R-squared } \\
\text { AdjustedR-squared } \\
\text { S.E. of regression } \\
\text { Sum squared resid } \\
\text { Log likelihood } \\
\text { F-statistic } \\
\text { Prob(F-statistic) }\end{array}$ & $\begin{array}{r}0.000022 \\
-0.001365 \\
2.201981 \\
3495.926 \\
-1595.596 \\
0.015900 \\
0.899692\end{array}$ & \multicolumn{2}{|c|}{$\begin{array}{l}\text { Mean dependentvar } \\
\text { S.D. dependent var } \\
\text { Akaike infocriterion } \\
\text { Schwarz criterion } \\
\text { Hannan-Quinn criter. } \\
\text { Durbin-Wats on stat }\end{array}$} & $\begin{array}{l}1.001106 \\
2.200479 \\
4.419354 \\
4.432033 \\
4.424248 \\
1.997496\end{array}$ \\
\hline
\end{tabular}

Sumber: Output Eviews Versi 9.

Menurut Tabel 2, model ARCH signifikan. Ini berarti terdapat penolakan hipotesis nol dan menerima bahwa ada efek ARCH pada JII return, karena adanya tingkat volatilitas di JKSE. Oleh karena itu, Model yang sesuai adalah $\mathrm{ARCH}$.

Tabel 3. GARCH model

Dependent Variable: JAKARTA ISLAMIC INDEX

Method: ML ARCH - Normal distribution (BFGS/Marquardt steps)

Date: 05/06/18 Time: 10:22

Sample: $1 / 30 / 20151 / 30 / 2018$

Included observations: 724

Convergence achieved after 28 iterations

Coefficient covariance computed using outer product of gradients

Presample variance: backcast (parameter $=0.7$ )

$\mathrm{GARCH}=\mathrm{C}(2)+\mathrm{C}(3)^{*} \operatorname{RESID}(-1)^{\wedge} 2+\mathrm{C}(4)^{*} \mathrm{GARCH}(-1)$

\begin{tabular}{crrrr}
\hline \hline Variable & Coefficient & Std. Error & z-Statistic & Prob. \\
\hline \hline C & 0.000238 & 0.000360 & 0.662468 & 0.5077 \\
\hline \hline Cariance Equation & & \\
\hline \hline RESID(-1)^2 & $2.74 \mathrm{E}-06$ & $9.24 \mathrm{E}-07$ & 2.966556 & 0.0030 \\
GARCH(-1) & 0.073240 & 0.013915 & 5.263273 & 0.0000 \\
\hline \hline R-squared & 0.907740 & 0.018014 & 50.38965 & 0.0000 \\
AdjustedR-squared & -0.000004 & Mean dependentvar & 0.000215 \\
S.E. of regression & -0.000004 & S.D. dependent var & 0.011548 \\
Sum squared resid & 0.011548 & Akaike info criterion & -6.224440 \\
Log likelihood & 0.096419 & Schwarz criterion & -6.199109 \\
Durbin-Watsonstat & 2257.247 & Hannan-Quinn criter. & -6.214663 \\
\hline
\end{tabular}

Sumber: Output Eviews Versi 9.

Selanjutnya, karena ada efek $\mathrm{ARCH}$, penelitian ini diikuti dengan menggunakan model GARCH. Namun, menurut Tabel 3, hasilnya positif

Ihtifaz: Journal of Islamic Economics, Finance, and Banking 
signifikan pada tingkat $1 \%$, yang menunjukkan menolak hipotesis nol dan menerima adanya pengelompokan volatilitas dalam series return nya. Dengan kata lain, volatilitas dari periode sebelumnya memiliki kekuatan untuk menjelaskan kondisi volatilitas saat ini. Selain itu, jumlah koefisien dalam model GARCH adalah ukuran stabilitas dalam guncangan volatilitas. Karena hasilnya sekitar 0,98 (dekat dengan satu) maka model ini lebih stabil terhadap guncangan untuk varian kondisional. Oleh karena itu, series return JKSE memiliki kedua atribut; volatilitas pengelompokan dan persisten.

Akhirnya, untuk menangkap ketersediaan perilaku asimetris dan adanya pengaruh leverage dalam pengembalian keuangan JKSE, digunakanlah model EGARCH. Diharapkan bahwa koefisien C (5) dalam model EGARCH harus negatif dan signifikan.

Tabel 4. EGARCH model

\begin{tabular}{|c|c|c|c|c|}
\hline $\begin{array}{l}\text { Dependent Variable: } \\
\text { Method: ML ARCH - } \\
\text { Date: 05/06/18 Tim } \\
\text { Sample: } 1 / 30 / 20151 / \\
\text { Included observation } \\
\text { Convergence achiev } \\
\text { Coefficient covarianc } \\
\text { Presample variance: } \\
\text { LOG(GARCH) }=\mathrm{C}(2) \\
\text { *RESID }(-1) /(@ S\end{array}$ & $\begin{array}{l}\text { ARTA ISLAMI } \\
\text { al distribution } \\
23 \\
23 \\
4 \\
\text { er } 41 \text { iteration } \\
\text { nputed using } \\
\text { cast (parame } \\
\text { 3)*ABS(RES } \\
\text { GARCH }(-1) \text { ) }\end{array}$ & $\begin{array}{l}\text { outer product of } \\
\text { ter }=0.7) \\
D(-1) @ S Q R T( \\
+C(5) * L O G(G A\end{array}$ & $\begin{array}{l}\text { radients } \\
\mathrm{ARCH}(-1)))+ \\
\mathrm{CH}(-1))\end{array}$ & $\mathrm{C}(4)$ \\
\hline Variable & Coefficient & Std. Error & z-Statistic & Prob. \\
\hline $\mathrm{C}$ & $-3.46 \mathrm{E}-05$ & 0.000372 & -0.092895 & 0.9260 \\
\hline \multicolumn{5}{|c|}{ Variance Equation } \\
\hline $\begin{array}{l}C(2) \\
C(3) \\
C(4) \\
C(5)\end{array}$ & $\begin{array}{r}-0.387724 \\
0.161170 \\
-0.065925 \\
0.970549\end{array}$ & $\begin{array}{l}0.099770 \\
0.030976 \\
0.021663 \\
0.009345\end{array}$ & $\begin{array}{r}-3.886170 \\
5.203064 \\
-3.043131 \\
103.8630\end{array}$ & $\begin{array}{l}0.0001 \\
0.0000 \\
0.0023 \\
0.0000\end{array}$ \\
\hline $\begin{array}{l}\text { R-squared } \\
\text { Adjusted R-squared } \\
\text { S.E. of regression } \\
\text { Sum squared resid } \\
\text { Log likelihood } \\
\text { Durbin-Watson stat }\end{array}$ & $\begin{array}{r}-0.000468 \\
-0.000468 \\
0.011551 \\
0.096464 \\
2261.116 \\
2.026615\end{array}$ & \multicolumn{2}{|c|}{$\begin{array}{l}\text { Mean dependentvar } \\
\text { S.D. dependent var } \\
\text { Akaike info criterion } \\
\text { Schwarz criterion } \\
\text { Hannan-Quinn criter. }\end{array}$} & $\begin{array}{r}0.000215 \\
0.011548 \\
-6.232366 \\
-6.200703 \\
-6.220146\end{array}$ \\
\hline
\end{tabular}

Sumber: Output Eviews Versi 9.

Tabel 4 menunjukkan output EGARCH. Semua parameter yang diperkirakan, signifikan secara statistik. Parameter C (5) adalah indikator untuk volatilitas asimetris. Karena nilai yang diharapkan adalah negatif signifikan, hasilnya menunjukkan sebaliknya, yaitu signifikan positif. Ini menunjukkan bahwa tidak ada dukungan untuk keberadaan leverage di Jakarta Islamic index (JII). Hasil ini juga menyiratkan bahwa guncangan terhadap saham, termasuk berita baik dan buruk yang dapat 
mempengaruhi Bursa Efek Jakarta, akan mempengaruhi volatilitas untuk waktu yang tertentu di masa depan, yang konsisten dengan temuan empiris dari studi terbaru sebelumnya.

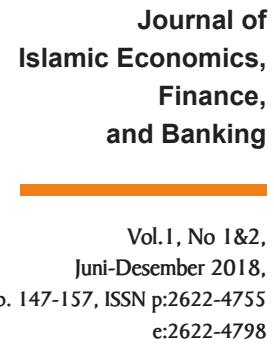

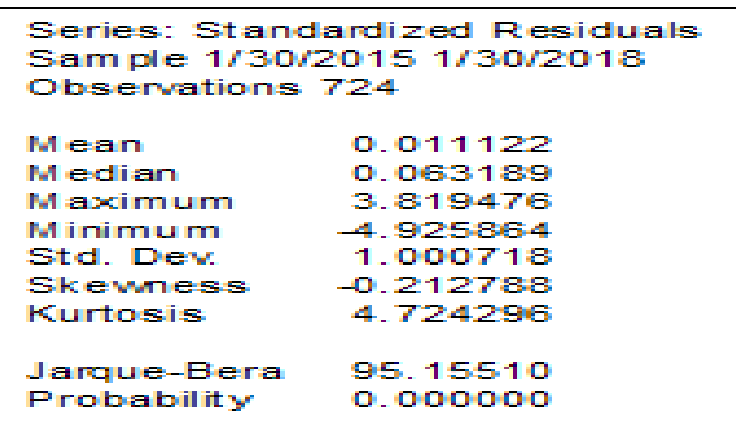

Tabel 5 dapat ketahui bahwa saham pada tahun 2015 sampai 2018 tidak cukup baik terlihat dari tidak terdistribusi secara normal, hasil nilai kurtosis terletak pada level $1 \%, \% 5$ dan $10 \%$ yang artinya menolak Ho (hipotesis nol), dan perubahan votalitas dari waktu ke waktu cenderung mengelompokkan return-nya.

Pada tahun 2105, pergerakan IHSG menurut CNBC Indonesia sepanjang pekan membuat gerah pelaku pasar. Dalam kurun satu minggu, IHSG anjlok hingga 6,6\% ke level 5.919,24. Hal ini disebabkan karena laju ekonomi dalam negeri tidak mampu memenuhi ekspektasi. Padahal pelaku pasar sebelumnya menaruh harapan yang tinggi ketika presiden baru mengambil alih kepemimpinan Indonesia pada 20 oktober 2014.

Pertumbuhan ekonomi quartal 1 diumumkan oleh BPS di angka $4,73 \%$, jauh lebih rendah dibandingkan konsensus yang di himpun oleh Reuters sebesar 4,95\%. Saat itu, tekanan bukan hanya datang dari sisi domestik melainkan juga dari sisi eksternal berupa rencana normalisasi suku bunga acuan oleh The Federal Reserve selaku bank sentral Amerika Serikat. Sepanjang tahun sudah cukup untuk membuat pelaku pasar bermain aman dengan melakukan aksi jual atas saham-saham yang dimilikinya. Jika The Fed menaikkan suku bunga, terdapat potensi aliran dana ke Amerika Serikat.

Sama seperti tahun 2015, pada tahun 2018 pemerintah mematok pertumbuhan ekonomi di angka 5,4\%, naik signifikan dari tahun sebelumnya sebesar 5,07\%. Optimisme pemerintah ini di topang oleh tahun politik, pemulihan daya beli masyarakat dan penyelenggaraan Asian Games. Namun daya beli masyarakat Indonesia masih lemah terlihat dari survey penjualan retail dan indeks keyakinan konsumen yang tidak menggembirakan. Hal tersebut tentu bukan kabar baik bagi bursa saham mengingat IHSG baru terkoreksi sebesar 11,5\% dimana terakhir kali terjadi pada 2015 dimana koreksi IHSG mencapai 25,4\%. Hal inilah 
yang menunjukkan kesesuaian keadaan antara tahun 2015 sampai 2018 dimana faktor-faktor internal dan eksternal menjadi penyebab anjloknya IHTIFAZ - JIEFB perekonomian Indonesia.

\section{KESIMPULAN DAN SARAN}

Pada tahun 2015 sampai 2018, saham di JII kondisinya tidak cukup baik, terlihat dari return nya tidak terdistribusi secara normal. Hasil nilai kurtosis terletak pada level $1 \%, 5 \%$ dan $10 \%$ yang artinya menolak $\mathrm{H} 0$ (hipotesis nol), dan perubahan votalitas dari waktu ke waktu cenderung mengelompokkan return-nya.

Dengan menggunakan metode GARCH diperoleh hasil positif yang cukup signifikan pada tingkat $1 \%$, yang menunjukkan untuk menolak hipotesis nol dan menerima adanya pengelompokan volatilitas dalam series return. Dengan kata lain, volatilitas dari periode sebelumnya memiliki kekuatan untuk menjelaskan kondisi volatilitas saat ini. Selain itu, jumlah koefisien dalam model GARCH adalah ukuran dari kestabilan dalam guncangan volatilitas. Karena hasilnya sekitar 0,98 (dekat dengan satu) maka itu berarti lebih kuat dalam menghadapi kejutan (shock) untuk varian kondisional. Oleh karena itu, series return JKSE memiliki kedua atribut; volatilitas pengelompokan dan persisten.

Hasil penelitian diketahui karakteristik return saham adalah rata-rata hasil pengamatan pada JII yaitu 0,011122 yang menunjukkan bahwa ada keuntungan selama periode pengamatan. Standard deviasinya 1,000718. Ada juga perbandingan nilai maximum $-4,92586$ yang menunjukkan variabilitas perubahan harga. Kurtosis variabel return nya 4.72296 dan skewness $-0,212788$. Data ini menunjukkan bahwa distribusi miring dan tidak terdistribusi secara normal. Hasil uji JarqueBera 95,15510 juga konsisten dengan nilai kurtosis dan kemiringan sebelumnya yang memiliki tingkat signifikasi pada level $1 \%, 5 \%$ dan $10 \%$ yang berarti menolak hipotesis nol dan menerima hipotesis alternatif yang menyatakan bahwa hasil pengamatan tidak terdistribusi secara normal.

Penelitian ini menyarankan bahwa tidak direkomendasikan bermain saham untuk kepentingan jangka pendek, apalagi untuk spekulasi. Hal ini disebabkan, kerugian yang sangat besar dapat terjadi sewaktu-waktu.

\section{REFERENSI}

Achsien, Iggi H. (2000). Investasi Syari'ah di Pasar Modal : Menggagas Konsep dalam Praktik Manajemen Portofolio Syari'ah. Jakarta: Gramedia Pustaka Utama.

Al-Najjar, Dana. (2016). Modelling and Estimation of Volatility Using ARCH/GARCH Models in Jordan's Stock Market. Asian Journal of Finance \& Accounting, Vol. 8, No. 1. 
Aggarwal, R., Inclan,C. dan Leal, R. (1999). Volatility in Emerging Stock Markets, Journal of Financial and Quantitative Analysis, 34. Vol.1.

Anton. (2006). Analisis Model Volatilitas Return Saham. Universitas Diponegoro.

Billah, Mohd Ma'ssum. (2009). Penerapan Pasar Modal Islam. Jakarta: Universitas Al Azhar Indonesia.

Haykal, Muhammad. (2012). Tuntunan dan aplikasi investasi Syariah. Jakarta: Elex Media Komputindo.

Huda, Nurul dan Mustofa Edwin Nasution. (2008). Investasi Pada Pasar Modal Syariah. Jakarta: Penerbit Kencana.

Ikatan Bankir Indonesia. (2015). Manajemen Resiko. Jakarta: Gramedia Pustaka Utama.

Irkhami, Nafis. (2010). Analisis Risiko dalam Investasi Islam. Muqtasid, vol. 1 No. 1.

Nastiti, Khoiru Liummah Ayu dan Agus Suharsono. (2012). Analisis Volatilitas Saham Perusahaan Go Public dengan Metode ARCHGARCH. Jurnal Sains Dan Seni ITS, Vol. 1, No. 1.

Romansyah. (2015). Pasar Modal Dalam Perspektif Islam. Mazahib: Jurnal Pemikiran Hukum Islam. Vol. 14. No. 1.

Soemitra Andri. (2014). Masa Depan Pasar Modal Syariah Di Indonesia. Jakarta: Kencana.

Sunariyah. (2003). Pengantar Pengetahuan Pasar Modal. Yogyakarta: UUP AMP YKPN.

Sutrisno, Bambang. (2017). Hubungan Volatilitas Dan Volume Perdagangan Di Bursa Efek Indonesia. Sensi: Jurnal Bisnis dan Manajemen, vol. 7. No. 1. April 2017.

Tanjung, Hendri., Abrista Devi. (2013). Metodologi Penelitian Ekonomi Islam. Bekasi: Gramata Publishing.

Tanjung, Hendri. (2014). Volatility of Jakarta Islamic Indeks. Jurnal Aliqtishad, Vol. 6, No. 2.

Umam, Khaerul. (2013). Pasar Modal Syariah \& Praktik Pasar Modal Syariah. Bandung: Pustaka Setia.

Winarno, Wing Wahyu. (2007). Analisis Ekonometrika Statistika dengan Eviews. Yogyakarta: UPP STIM YKPN.

Yohanes S., Yun H. (2003). Peramalan dalam Selang GARCH(1,1). WPF Bandung FE Institute.

Yohanes S., Yun H. (2003). Kulminasi Prediksi Data Deret Waktu Keuangan Volatilitas dalam GARCH(1,1). WPF Bandung FE Institute.

Yuliana, Indah. (2010). Investasi Produk Keuangan Syariah. Malang: UIN-Maliki Press.

Journal of

Islamic Economics,

Finance,

and Banking

Vol.1, No 1\&2, Juni-Desember 2018, pp. 147-157, ISSN p:2622-4755 e:2622-4798

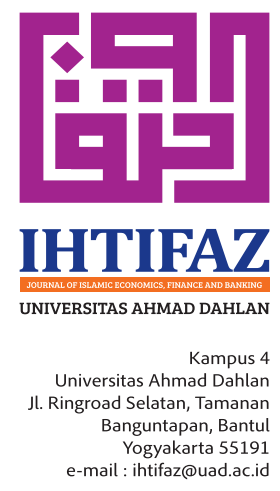

